\title{
'Kollegah the Boss': A case study of persona, types of capital, and virtuosity in German gangsta rap
}

\author{
MICHAEL AHLERS \\ Leuphana University, Lueneburg, Germany \\ E-mail: michael.ahlers@leuphana.de
}

\begin{abstract}
The article begins with a short history of German gangsta rap, followed by an overview of central theories and key concepts in hip-hop studies. It then focuses on a case study of a German gangsta rapper called Kollegah, who became one of Germany's most commercially successful artists of the past few years. The case study is divided into three parts: the first involves a deconstruction of both his artistic persona and his strategies of appropriating hip-hop cultures. This is followed by a closer look at two Kollegah productions, focusing on his rhyming and signifying skills. By adding a cursory qualitative media analysis of both Internet fan forums and print and television artefacts about Kollegah, very contradictory reactions can be depicted. The article is finally able to illustrate that this artist makes great use of a (typically German?) flavour of virtuosity and that he can draw from a very unique set of capital. Kollegah is viewed as representing a successful strategy of cultural appropriation and the use of different types of capital within the network of music business in its post-digital era.
\end{abstract}

\section{Introduction}

Just like global developments on mainstream markets, most of the traditional music businesses in Germany were strongly affected by digitalisation. Unsurprisingly, it was the independent artists and their small record labels who quickly took advantage of the new strategies for value creation available within this setting. Within the German rap scene there were - and still are - quite a few record labels, such as Aggro Berlin, Chimperator and Selfmade Records, that signed on, professionalised and marketed some of the most well known and successful rap artists since the beginning of the twenty-first century (such as B-Tight, Bushido, Massiv, Baba Saad and Sido). It is quite striking that their strategies focus mainly on the use of social media, merchandise and live concerts, rather than on traditional promotional activities that prioritised radio and music television.

This paper will first provide a very brief introductory overview of the history of German rap and then take a look at some of the essential theoretical frameworks that are to be found among international scholars. This will serve to illustrate some of the key concepts that are essential for this paper's own approach. Concepts of international hip-hop studies and the theory of 'acoustic capital' will both be applied in 
a case study of the German gangsta rap artist Kollegah, who became one of the biggest selling acts in the history of Germany's rap and music business in the new millennium. After that, findings from a qualitative analysis of media products and fan forums will be used to identify specific stagings as well as the perception of virtuosity connected to this artist. Finally, these findings will be discussed on the basis of theories of appropriation and authenticity.

\section{Historical and theoretical concepts}

In the 1980s, hip-hop culture hit Germany with early adaptations by conscious rap artists such as Advanced Chemistry and Cora E. on the one hand, and fun rap acts such as Die Fantastischen Vier (Fantastic Four) on the other (cf. Güler Saied 2012, pp. 55-69; Verlan and Loh 2006; Pennay 2001). Today, rap is one of the most successful musical genres in Germany, ranging from popular styles to hardcore or gangsta rap, and hip-hop is still one of the dominant youth cultures. ${ }^{1}$

In the early 1980s, there was a first wave or 'school' of rap artists (such as Advanced Chemistry) that explicitly addressed their own migrant backgrounds, as well as a number of counterparts in the field of racist rap (cf. Bower 2011; Güngör and Loh 2002). Because of historical developments following the end of World War II, there are a great many Turkish migrants living in Germany whose parents or grandparents originally came to the country as Gastarbeiter (migrant labourers) and stayed on. This is why a wealth of academic work on this migrant culture, its languages and cultural practices (cf. Barth 2013; Kaya 2007; Solomon 2006; Wurm 2006; Bennett 2004; Soysal 2004; Kimminich 2004; Ickstadt 1999; Elflein 1998; Becker 1996) can also be found. These analyses often mention the frequently explicit lyrics used in porno rap (cf. Weller 2010) and the motifs or discourses of gangsta rap as the preferred styles and topics of these artists.

Although it originated in the USA, gangsta rap became an underground, later a subcultural, phenomenon in Germany in the 1990s with rappers such as Rödelheim Hartreim Projekt, Kool Savas or Azad, before Sido and his supervising production company and record label Aggro Berlin sold more than 100,000 copies of his gangsta rap album, and as a result, were awarded gold status in the German Hot 100. Hence it was these companies who took this subgenre of rap music into the mainstream markets. The artists of this subgenre, such as B-Tight, Bushido, Fler and Kitty Kat, were among the best-known and best-selling musicians. However, just like in the US, German politicians and the media targeted gangsta rap because of its extreme lyrics, which featured elements of homophobia, xenophobia, violence, drug abuse and misogyny. Indeed, the overall reception of German gangsta rap is very contradictory, oscillating between fandom, commercial success, and ethical and legal problems. Today, its public perception can be summed up by the words of social psychologist Jürgen Straub:

Gangsta-Rap steht, in welcher Spielart auch immer, für ein gemeinsames und verbindendes Lebensgefühl, nicht zuletzt für einen Kampf um Anerkennung, Selbstbehauptung und Selbstbestimmung von zumeist jüngeren Generationen, die im Ringen um einigermaßen attraktive Handlungs- und Lebensorientierungen sowie zukunftsträchtige Perspektiven eine vielschichtige und längst $>$ erfolgreiche $<$ Identitätspolitik betreiben. [...] Die Massenmedien

${ }^{1}$ For an up-to-date overview of German youth cultures see: www.jugendkulturen.de or: www.jugendszenen.com. 
begleiten den oft spektakulären Ausdruck eines kollektiven Lebensgefühls mit voyeuristischer Angstlust und zugleich mit dem erhobenen Zeigefinger moralischer und politischer Autorität. (Straub 2012, pp. 8-9)

Gangsta rap in all its forms stands for a collective and unifying attitude towards life and in particular for a largely younger generation's struggle for recognition, self-assertion and self-determination. These generations strive to create reasonably attractive life and action orientations for themselves and better perspectives for their future by practising a multi-faceted and successful form of identity politics. [...] These frequently spectacular expressions of a collective attitude towards life are accompanied by a combination of voyeuristic thrill-seeking and the stern judgement of moral and political authority in the media. (Translation: M.A.)

Nowadays, a huge number of articles and books on German hip-hop are available in a wide range of fields: from literary studies (Wolbring 2015; Würtemberger 2009) to sociology (Schröer 2013; Friedrich and Klein 2003), musicology (Elflein 2014; Hörner and Kautny 2009; Elflein 1998) and education (Hofmann 2015; Loh 2013; Anders 2007). Extensive anthologies have even been published on both German hip-hop culture (Dietrich 2015; Bock et al. 2007) and gangsta rap (Dietrich and Seeliger 2012). Some of the central concepts or discourses will be addressed here in succession, sometimes cautiously expanded by integrating international perspectives or discourses. These will later be used for the case study of Kollegah (analysis I, see Figure 1).

\section{Concepts}

\section{Migration and Diaspora}

In Germany, it took quite a long time before the concept of being a country of immigration (cf. Güler Saied 2012, p. 122) became a topic of political debate and, with new

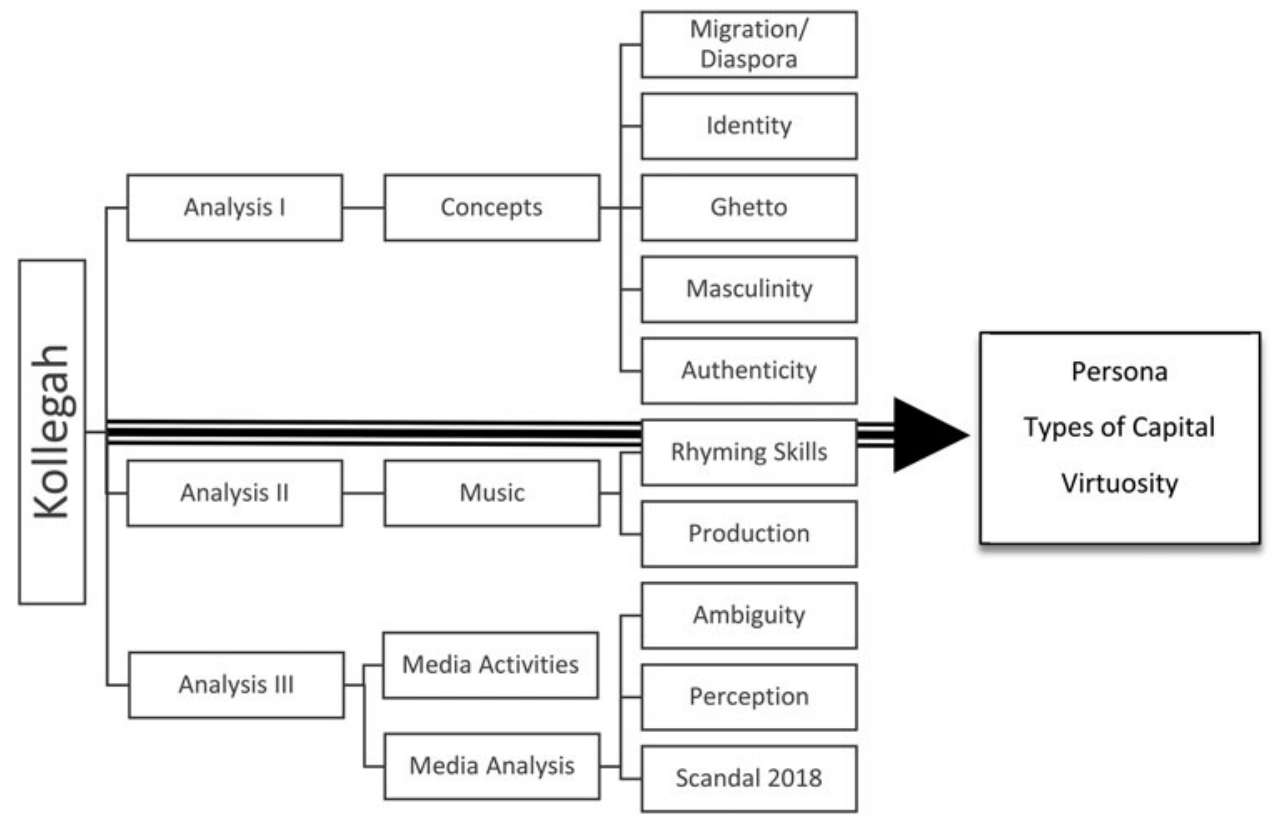

Figure 1. Concepts and layers of analyses of Kollegah the Boss. 
nationalist movements appearing all over Germany and the rest of Europe since 2010, these discussions are being picked up once again. Following several somewhat abortive multicultural approaches (cf. Merkt 1993; Böhle 1996), a range of intercultural and transcultural concepts of migration and cultural integration (cf. Schütz 1998; Ott 2012) were developed. Yet there is still an ongoing and very lively debate - especially after the onset of large-scale refugee movements from Syria, Africa and Eastern Europe in 2015 - on processes of acculturation, transculturation, integration and so forth (cf. Heckmann 2015; Barth 2013; Heyer et al. 2013; Meyer 2007).

In addition, the concept of (transnational) diaspora and diasporic music cultures has been applied to hip-hop culture in recent years (Güney et al. 2014) and works using postcolonial theory and analysis have been published (Ismaiel-Wendt 2011). These works were widely received in German-speaking popular music studies. Since the central analysis of Kollegah will attempt to illustrate his broad use of knowledge, skills, and his specific persona and habitus, this will be linked back to the idea of diasporic and migrant cultures.

\section{Global and local identities}

Since the mid-1990s, German rap music has developed various local styles and strands, some of which are still closely related to their African-American roots, while others are rather more divergent. As Tony Mitchell puts it:

Hip-hop and rap cannot be viewed simply as an expression of African American culture; it has become a vehicle for global youth affiliations and a tool for reworking local identity all over the world. Even as a universally recognized popular musical idiom, rap continues to provoke attention to local specificities. (Mitchell 2001, pp. 1-2)

Today, German rap therefore offers a wide range of 'glocal' (cf. Robertson 1995) artistic identities and aesthetic strategies or narratives to choose from. As mentioned before, these are very often copies/adaptations/appropriations of US American archetypes or even subcultures, with slight to medium local customisations. These include the self-representations and performances listed in the following, with the artist names in parentheses serving as German examples:

- the pimp (e.g. Bushido, Kollegah);

- the criminal (e.g. Xatar);

- the hero (e.g. Samy Deluxe);

- the buffoon (e.g. Dendemann);

- John Citizen (e.g. Alligatoah);

- the bitch (e.g. Lady Bitch Ray).

The artists listed above do not represent a single identity, persona or performance strategy, as most of the concepts are sometimes intertwined. Instead, the artists tend to choose a specific mixture. This is because prototypes or narratives need to be 'refreshed', as Miles White writes:

In hip-hop culture, uniqueness and the expression of individual identity are prioritized through behavior, modes of dress, language, and other ways. Even when styles and expressive behaviors are emulated, imitated, and adopted by those wishing to identify with the culture, they are often at some point adapted and signified upon - there are those who 
innovate and those who 'bite' (appropriate) the innovations of others. In this way, expressive behaviors continue to evolve, continually creating something new from something old, always seeking that which is 'fresh'. (White 2011, p. 32)

However, as Tricia Rose puts it, all narratives or idioms are commercialised at a very early stage in their appearance too. This raises issues of stigmatisation:

Via commercial industries, new technologies and mass media outlets, rappers attempt to rewrite, rearticulate and revise popular, national, and local narratives. Rappers negotiate these narratives from a peculiarly contradictory position of social vulnerability and cultural clout. By this, I mean that, although rappers are some of the most prominent social critics in contemporary popular culture, they remain some of the most institutionally policed and stigmatized. (Rose 1994, p. 184)

\section{Urbanity and (imagined) ghettos}

The historical background of the ghetto in Germany differs significantly from US, Brazilian or African constructions of these social conditions and living spaces. The term ghetto was used as early as the Middle Ages, referring to a designated area in which people of a specific ethnic group were forced to live. This continued until the end of World War II. Following post-war migration, the term ghetto was used to describe areas located on the outskirts of cities that were mainly inhabited by migrant labourers, later also by refugees. Very often these areas were called 'soziale Brennpunkte' (socially vulnerable areas). This led to the stigmatisation of the inhabitants of these marginalised areas by politicians and the media (Ottersbach 2009), but also to their use as a trope in German hip-hop cultures. Ever since the term itself was introduced in 1980s rap lyrics, it has undergone various developments. The term itself is still frequently used in German music culture and especially in rap lyrics today - but with slightly differing intentions, as Ayla Güler Saied writes:

Die Erzählung über das Ghetto oder die Ghettoisierung einzelner Stadtteile wird im medialen sowie politischen und auch wissenschaftlichen Kontext oftmals genutzt, um Stadtquartiere mit hohem Migrationsanteil zu thematisieren und gleichzeitig auch zu problematisieren. Daneben ist der Begriff Parallelgesellschaft [...] ein weiterer Funktionsträger, wenn es um die Konstruktion von Fremdheit im städtischen Diskurs geht. [...]

Somit gibt es in der Bundesrepublik Deutschland lediglich imaginierte Ghettos, die fiktiv konstruiert werden. [...] Wesentlich außer Acht gelassen wird dabei die finanzielle, soziale und politische Dimension der Vernachlässigung dieser Quartiere. Dies dient dazu, den Leidtragenden die Verantwortung für die prekäre und marginalisierte Situation in solchen Quartieren zuzuschreiben. (Güler Saied 2012, pp. 128-31)

The narrative of the ghetto or the ghettoisation of individual urban areas is frequently used by the media, politicians and even academics to address and at the same time problematise neighbourhoods with a large migrant population. The term parallel society [...] is also used to construct foreignness/otherness in an urban discourse. [...]

The only ghettos in Germany, therefore, are imaginary ones: fictitious constructions. The financial, social and political dimensions of the neglect suffered by these neighbourhoods are not addressed. This serves to assign the responsibility for the precarious and marginalised conditions in these neighbourhoods to the people they affect. (Translation: MA)

This can be compared with international developments, and might also be analysed in terms of occupied spaces, as Rollefson puts it in her comparison: 
As we will see, once occupied in geography, media and/or discourse, the ghetto functions as a powerful site from which non-white Europeans can lay claim to their nations, diversify the (white) body politic, and call for the aid that has been withheld from their communities on the basis of legalized frameworks of citizenship. (Rollefson 2013, p. 228)

Visual codes and representations of urbanity or ghetto life have been used in German rap videos or album covers almost from the very first adaptations of hip-hop culture. Metropolitan skylines, large housing estates, and graffiti writings, tags or pieces are common metaphors (cf. Mager and Hoyler 2007, p. 46). However, to become part of this whole urban culture, every artist or fan has to learn to read and decode these signs:

The texts that construct the culture constitute a kind of literacy that has now been largely internalized by youth worldwide to form a community of practice that identifies with hip-hop as a social and/or cultural movement or merely as a means of interpersonal interaction and pleasure. [...] This literacy is not only a literacy of music and rhetoric but a literacy of the body and the visual. (White 2011, p. 33)

\section{Masculinity}

As the two feminist researchers Anne Lenz and Laura Paetau have pointed out, gangsta rap in Germany is also a male-dominated subgenre of rap that includes extreme behaviour, representations of violence, or even violent performances on the part of its protagonists:

Traditionell findet Ermächtigung im Gangsta-Rap - so auch bei Bushido - durch männlich konnotierte Strategien wie den Rückbezug auf körperliche Überlegenheit, Mut, Omnipotenz und physische Gewalt statt. Die Erniedrigung von Frauen und Schwulen ist dafür der billigste Weg. (Lenz and Paetau 2012, pp. 114-5)

Traditionally, empowerment in gangsta rap - as with the artist Bushido - is based on male connoted strategies of physical superiority, courage, omnipotence and physical violence. The easiest way to achieve this is to degrade women or gay men. (Translation: MA)

Women are underrepresented in this subgenre, in Germany as well as in other parts of the world. Representations of women in gangsta rap videos are often restricted to erotic poses, or as dancers or status symbols. Although there are a few female rappers using narratives of gangsta and porno rap - one notable example in Germany is Lady Bitch Ray (cf. Tuzcu 2017) - they are reduced to being female $M C$, which might be read as doing gender, as Judith Butler describes it. In her case study of German female MCs, Ayla Güler Saied summarises that the rappers she interviewed try to create representations of simply being an artist, without being stigmatised for their status as a migrant or a woman. However, this turns out to be very difficult because of the power of male-dominated discourses and the rap music business as a whole (Güler Saied 2012, p. 264).

Malte Gossmann addresses the constitution and usage of masculinity as a concept or sociological process in the analysis of two types of male rap artists widely deemed offensive (2012). By applying Connell's concepts of hegemonic masculinity, Pierre Bourdieu's theory of habitus theory, and the joint approach taken by Michael Meuser, he depicts a wide scope, ranging from violence to irony. This is a rather crucial aspect of (gangsta or hardcore) rap, as Miles White illustrates: 
The appeal of hardcore rap and the macho posturing characteristic of battling rapping is like boxing, masculine desire as voyeurism, part fantasy, part fetish. (White 2011, p. 68)

All these findings appear to have one aspect in common: that of demarcation, in particular with respect to the boundaries between dominant ('male, heterosexual') and weak ('female, homosexual') parts of communities (cf. Gossmann 2012, pp. 102).

\section{Authenticity and skills}

Some of the strongest narrative focuses in rap music are on issues such as skills, the American from rags to riches myth, and aspects of authenticity, e.g. realness or (street) credibility. The image or concept of the hustler or pimp appears to be of equal importance when creating or analysing male rap persona:

As a tactic to confirm their authenticity as authentic ghetto subjects, many performers insist that drug dealing was their profession prior to making it as an artist. (Jeffries 2010, p. 96)

In his analysis of the history of Jay-Z, Shawn Carter even writes that 'the story of the rapper and the story of the hustler are like rap itself, two kinds of rhythm working together, having a conversation with each other, doing more together than they could do apart' (Carter 2010, p. 10). Yet Jay-Z seems to be one of the few artists whose authenticity appears to have been barely corrupted by his giant success and fame:

If hip-hop in the post-old school period had largely painted pictures of poverty, violence, and hustling, Jay- $Z$ has sought the interiority of feeling and the actualization of human experience that Robert Plant Armstrong articulates in terms of the affecting presence, and of exteriorizing that experience. If this art resonates with authenticity, if this street credibility remains intact after a decade and a dozen platinum albums, it is because it gets inside 'the interior space of a young kid's head, his psychology', and humanizes the often dehumanizing experience of being black and impoverished, of hustling street drugs for spare change and being willing to kill or die for it because the alternatives appear no better. (White 2011, pp. 83-4)

Besides this, rap artists also can preserve their authenticity or remain respected on the basis of their rhyming flow or poetic skills. Or, as Michael P. Jeffries states more precisely:

Instead, a culture community of hip-hop fans emerges, and these aestheticians prioritize lyrical content, technique (flow), and signifying (layered meaning) as the principles that are important to rap music. Black and white respondents at all class levels report that being a skilled signifier is especially vital to being considered a good MC. (Jeffries 2010, p. 146)

Although artists and fans alike may be able to clearly recognise a skilled performer with a specific flow containing layered meanings (signifying) or wordplay, academics continue to discuss what the appropriate methods of analysis are for this subject. Fabian Wolbring recommends the G.A.T. system, an abbreviation for conversation-analysis-transcription. In this system, accents are clearly marked, while filled and unfilled circles above the lyrics mark either strong or weak emphases of the beats/measures below (see Figure 2).

A more elaborate two-part system with a more explicit grounding in musical practice is proposed and illustrated by Oliver Kautny (2009, 2015). It combines both specifics of lyrical structure(s) and accents, and rhythmical rigour (see Figure $3 a$ and $b$ ): 


\section{Types of capital}

All the concepts and historical discourses will be applied or deconstructed in the persona of Kollegah in the following case study. A theoretical framework was needed for this purpose. Adopting Pierre Bourdieu's 'Forms of Capital' (1986) seemed an obvious choice, because a connection between strategies of appropriation, skills, knowledge and economic power was needed. In his theory, Bourdieu differentiates between social and cultural types of capital and illustrates their structure and associated types of conversion. He considers economic capital to be at the root of these types of capital, while cultural and social capital may also function as symbolic capital. The theory focuses mainly on social injustice, yet it may serve as a blueprint for contextualising Kollegah's specific set of capital in general.

There have been recent elaborations on this theory that have added to or modified parts of it: firstly, Bourdieu himself introduced the importance of language and linguistic capital in socio-economic linguistic fields (Bourdieu 1991, 1993). This

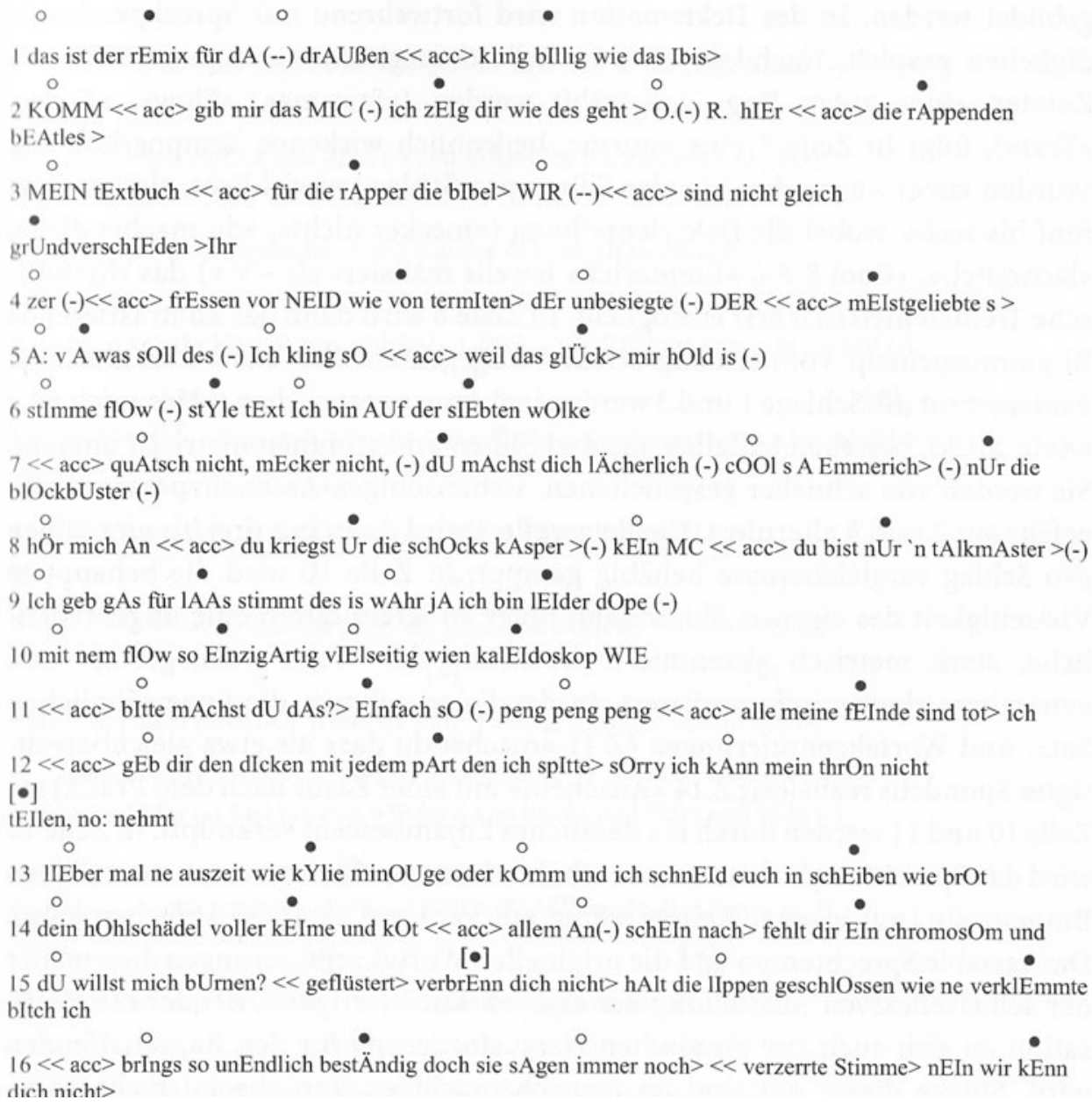

Figure 2. Lyrical analysis (snippet) of the song 'Wir kenn dich nicht reloaded' by Kool Savas (Wolbring 2015, p. 305). 
(a)

(b)

\begin{tabular}{|l|l|}
\hline Reim & \\
\hline 1 & $\begin{array}{c}\text { A } \\
\text { In euern billigen Raps auf unchilligen Tracks, redet ihr/ }\end{array}$ \\
\hline 2 & übers real keepen, Gewalt, Phillies ${ }^{\mathbf{8}}$ und ${ }^{9}$ Sex, was an/ \\
\hline 3 & $\begin{array}{l}\text { B } \\
\text { sich nicht schlimm ist, doch ich weiß, ihr lügt wie gedruckt und könnt es/ }\end{array}$ \\
\hline 4 & $\begin{array}{l}\text { B } \\
\text { nicht mit skills ausgleichen, denn ihr übt nicht genug/... }\end{array}$ \\
\hline
\end{tabular}
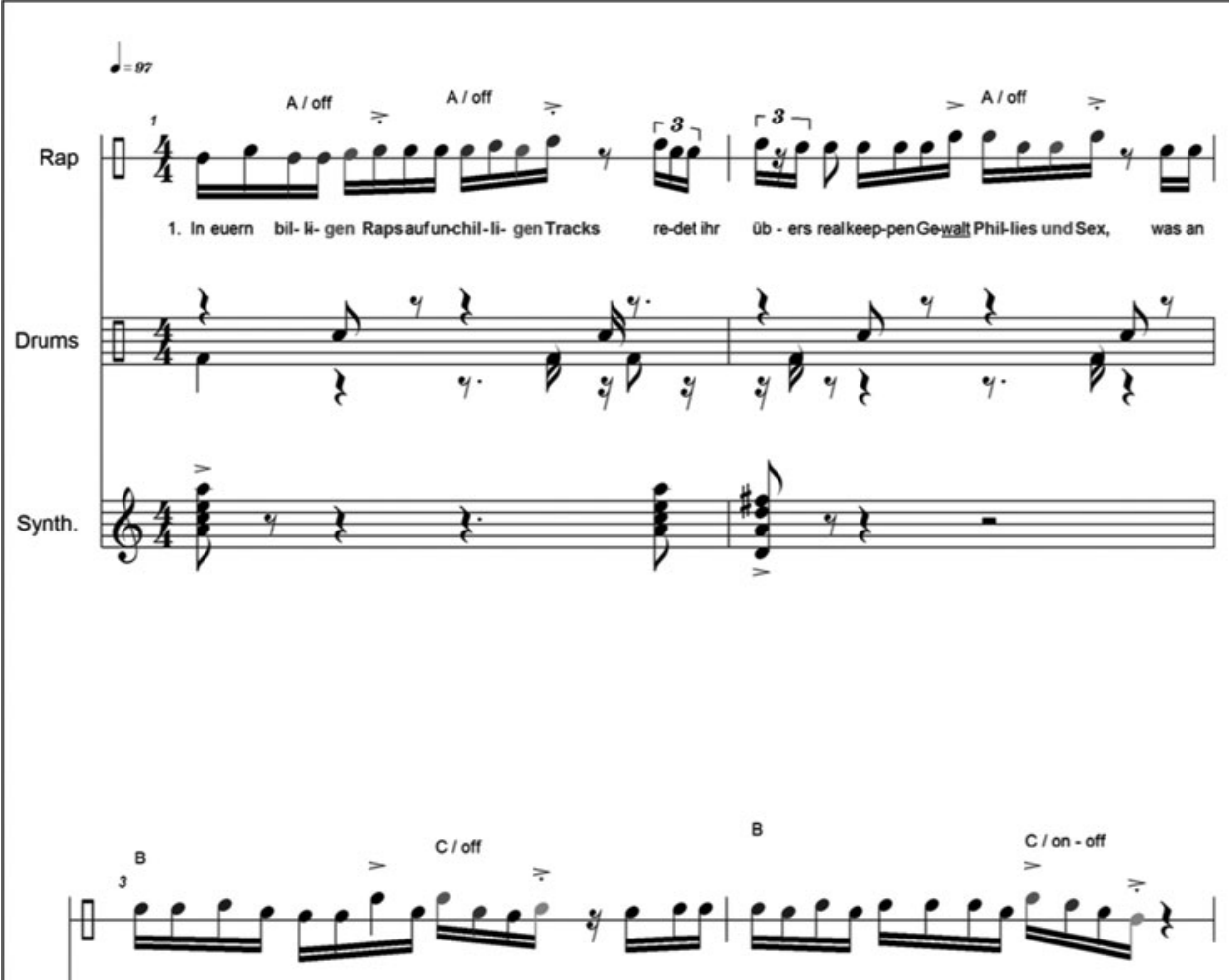

sich nicht schlimm ist, doch ich weiß, ihr lugt wie gedruckt und könnt es nichtmitskills ausglei-chen, denn ihr ubt nicht ge-nug.

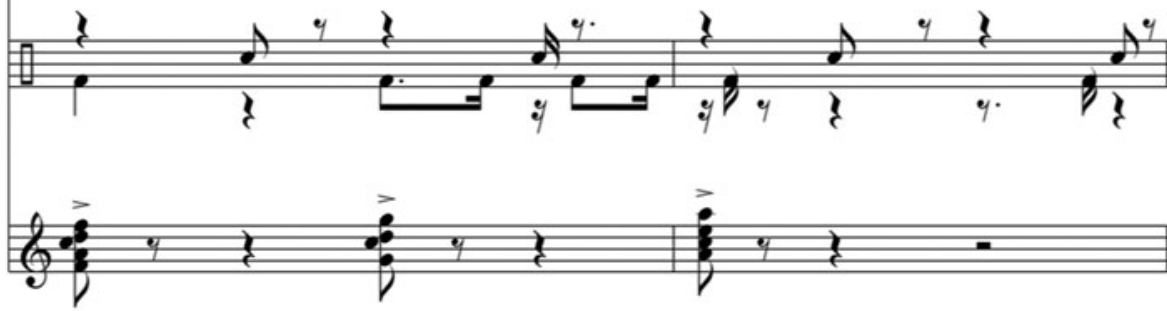

Figure $3 a$ and $3 b$. Analysis of rhyme scheme/structure and rhythmic specifics of a German rap song by Samy Deluxe (Kautny 2009, pp. 150-51). 
concept is often used in economic or pedagogical studies. It is very useful when trying to illustrate aspects of linguistic hegemonies or structures of dominant vs. nondominant cultures. In this study, it was considered less important, even though the study's focus is on a music style which is centred around linguistic and signifying skills.

Another take on Bourdieu's types of capital is that of Bürkner et al. (2013). They started with ethnographic studies of small electronic dance cultures and elaborated their own approach by conducting expert interviews with music producers, performers, fans, music industry representatives and others. Their concept of 'acoustic capital' is based on twenty-first century, post-digital settings. In these contexts, consumers attain equivalence with producers by means of their set of knowledge, or 'acoustic capital'. This type of capital is gained by producing, communicating, sharing or distributing artefacts. Economic capital is not as important as in the original work. This is quite oppositional to some aspects of Bourdieu's approach to embodied, objectified or institutionalised cultural capital. It points out new power relations in music businesses of the twenty-first century and underlines the importance of social media, user-generated content, artistic self-management and do-it-yourself cultures in music:

Akustisches Kapital ist ein Vermögen, das professionelle Akteure und 'Nutzer' (Konsumenten) erwerben, indem sie musikalische Güter bzw. Produkte schaffen, bearbeiten, verteilen und konsumieren. Dieses Vermögen ist mit spezifischen Wissensformen verbunden, die es den Akteuren ermöglichen, sich über die Qualität, die Kontexte und die Prozeduren der musikalischen Produktion und Konsumtion zu verständigen. Akustisches Kapital kann zunächst als seine feldspezifische, spezielle Form des Bourdieuschen kulturellen Kapitals begriffen werden. Während Bourdieu mit seinen Typen des kulturellen, ökonomischen und symbolischen Kapitals jedoch grundlegende Determinanten sozialer Ungleichheit identifiziert, wird hier stärker auf variable Austauschprozesse zwischen Kapitalsorten, Akteuren und Gütern innerhalb von begrenzten sozialen Feldern abgehoben. (Bürkner et al. 2013, p. 27)

Acoustic capital is a capacity that professional actors and users/consumers gain by creating, editing, distributing or consuming musical goods or products. This capacity is connected to specific types of knowledge that allow the actors to communicate with each other about the quality, contexts and procedures of musical production or consumption. Acoustic capital may be viewed initially as a particular, field-specific type of Bourdieu's cultural capital. While Bourdieu's categories of cultural, economic and symbolic capital are used to identify the underlying factors that determine social inequality, [acoustic capital] places a stronger emphasis on the variable processes of exchange between different types of capital, actors and goods within a circumscribed social field. (Translation: MA)

Additionally, the study attempts to include aspects of the theory of 'Aufmerksamkeitsökonomie' (attention economy). This underlines the importance of attention, or fans' and the industry's perception of artists or artefacts as well as aspects of communication, in the past via radio or television, but more recently mainly through social media. Some authors assert that, in post-digital music economies, attention capital might be even more important than economic capital (Gebesmair 2018; Herzberg 2014). Since most of these studies emphasise the importance of media communication, self-marketing, changing roles and power relations between industries, artists and consumers, this seemed to fit with the theoretical aspects of acoustic capital. It is now up to the case study to disentangle those intertwined sets of knowledge, skills and strategies of Kollegah - with a strong emphasis on the artist's use of the media and the media's or fans' reactions to his perceived 
virtuosity - to evaluate this and his perceived cultural, symbolic and acoustic types of capital.

\section{Case study: Kollegah the boss}

\section{Biographical background}

Kollegah was born under the name Felix Antoine Blume in Germany in the year 1984. His Canadian father left his German mother early on, and so he grew up with an Algerian stepfather, who is credited with inventing the nickname Kollegah (a colloquial variant of the word colleague). He grew up in a small town in Rhineland-Palatinate, West Germany. He completed his secondary education with a university-entrance diploma. In 2017, he was still enrolled for law studies at the University of Mainz.

\section{Releases and awards}

Before calling himself Kollegah, he chose the nickname T.O.N.I. Kollegah's first appearance as an artist was as a contestant in a series of rap contests that were broadcast only on the Internet. One of these, called Reimliga Battle Arena (Rhyme League Battle Arena) and located in Hamburg, had served as a stepping stone for various rap artists since the beginning of the new millennium. After winning some of these battles, he released his first mix-tape called Zuhältertape Vol. 1 (Pimp Tape, vol. 1) as a free download on the Internet. It was followed by his second mix-tape (Boss der Bosse). He was then signed on by the independent label Selfmade Records in 2005. In 2014, Universal Music later offered the label a joint venture for future releases, with Universal initially taking on the distribution side of the business. Universal first reissued Kollegah's first mix-tape before releasing his first studio album Alphagene in 2007. This album went to number 51 in the German Hot 100 charts. His second, self-titled album made it to number 17 as early as 2008. In 2009, a collaboration album with rapper Farid Bang called Jung, brutal, gutaussehend /JBG (Young, brutal, good-looking; number 30 in the charts) and a third mix-tape entitled Zuhältertape Vol. 3 (Pimp Tape, vol. 3) were both released by Selfmade Records. In 2010, Hoodtape Vol.1 was released, followed by Bossaura (number 5) in 2011, Jung, brutal, gutaussehend 2 (number 1 in Germany, Austria and Switzerland) in 2013, King (number 1 in Germany, Austria, Switzerland) in 2014, Zuhältertape Vol. 4 (number 1 , plus 15 million streams on Spotify in one week and 15 album tracks on Spotify's Top 50) in 2015, Imperator (number 1 in Germany, Austria, Switzerland) in 2016, and finally Jung, brutal, gutaussehend 3 (number 1 in Germany, Austria, Switzerland) in 2018, continuing this success story.

Kollegah received several awards for his albums (gold and platinum awards, based on units sold and downloads) but was also awarded 'Best Web Video' in 2014, 'Best Hip-Hop Act' in 2014 and four Echos (awarded by the German music industry) for both 'Best Artist Hip-Hop/Urban National' and 'Best Interactive Act National'. The latter will be of special interest in the upcoming analysis. Besides industry prizes, he also won 10 prizes awarded by the website hip-hop.de, ranging from 'Best Punchline' to 'Best Rap Act'. Kollegah founded his own record label and 
media company Alpha Music Empire in 2016; distribution has since been taken over by Warner Music.

\section{Analysis I \\ Ghetto, migration, identity, masculinity, capital}

Kollegah was initially viewed as a follow-up to the successful Berlin style of gangsta rap performed by artists such as Sido or Bushido, but this perception has changed in the past few years. After the decline of this particular style and the (at least physical) closing down of the record label Aggro Berlin, he is one of the artists who guarantee the survival of the genre. His socio-cultural background serves rather poorly as an adequate story of the ghetto kid, but Kollegah stresses the fact that he grew up very poor and does have a criminal past (see below). He uses this statement to build on his artist's persona: Kollegah the boss as a ghetto-based pimp, surviving gang battles and mocking the police or the law. Evidence of this can be found in a large number of titles on his albums, which illustrate this in the lyrics (e.g. 'Ghettobusiness', 'Ghettosuperstars', 'Ghettoboys', 'Ghettoworkout'). His web music videos, as well as his official music videos, also depict this.

Kollegah emphasises his bi-cultural roots (French-Canadian/German). Because some early attacks in rap battles targeted him for his French middle name (Antoine), he flipped this apparent weakness into a strategy he has worked with ever since. Furthermore, he repeatedly refers to his conversion to Islam at the age of 15, which was inspired by his stepfather. In interviews, he regularly mentions having translated Islamic books into German before launching his rap career. This is important because quite a lot of young, male, migrant-German gangsta rap fans actually do have an Islamic religious background. It is quite evident that Kollegah chooses different aspects of migration or diaspora to build his specific story and to gain realness or authenticity of positionality (cf. Taylor 1997, p. 22) within German hip-hop culture.

It is evident that his artistic identity or persona is a mixture of the hustler, criminal and pimp stereotypes illustrated above. He very soon establishes his selfrepresentation as the boss, even using this for his album titles (Boss der Bosse [Boss of Bosses], Bossaura). From the very beginning of his career, most of his lyrics focused on these aspects: drug dealing (from soft drugs/weed to hard drugs/cocaine), violent behaviour towards opponents or women, sexually explicit phrases and exaggerated descriptions of wealth. In doing so, Kollegah attempts to refer to (or copy?) internationally successful artists such as 50 Cent or Jay-Z: 'Jay-Z also happens to have been the most successful and articulate rap artist of his generation, single-handedly reframing the ghetto fabulous street thug as the penthouse Mafioso impresario' (White 2011, p. 81). To ground and authenticate this part of his capital, two stories are disseminated in the media: first of all, he was charged with grievous bodily harm after a fight inside a discotheque in 2013. The case was closed following a financial settlement. Secondly, he was arrested for drug possession once but also got off with a fine and a community sentence. On various album covers, he uses symbols of drug dealing to signify this: from lines of cocaine and credit cards to money and straws used to snort drugs. He has also gotten into fights with other artists and even fans at concerts more than once.

The boss narrative and artistic persona can be highlighted as the essential strategy and incorporation of Kollegah's types of capital. He is clearly able to appropriate 

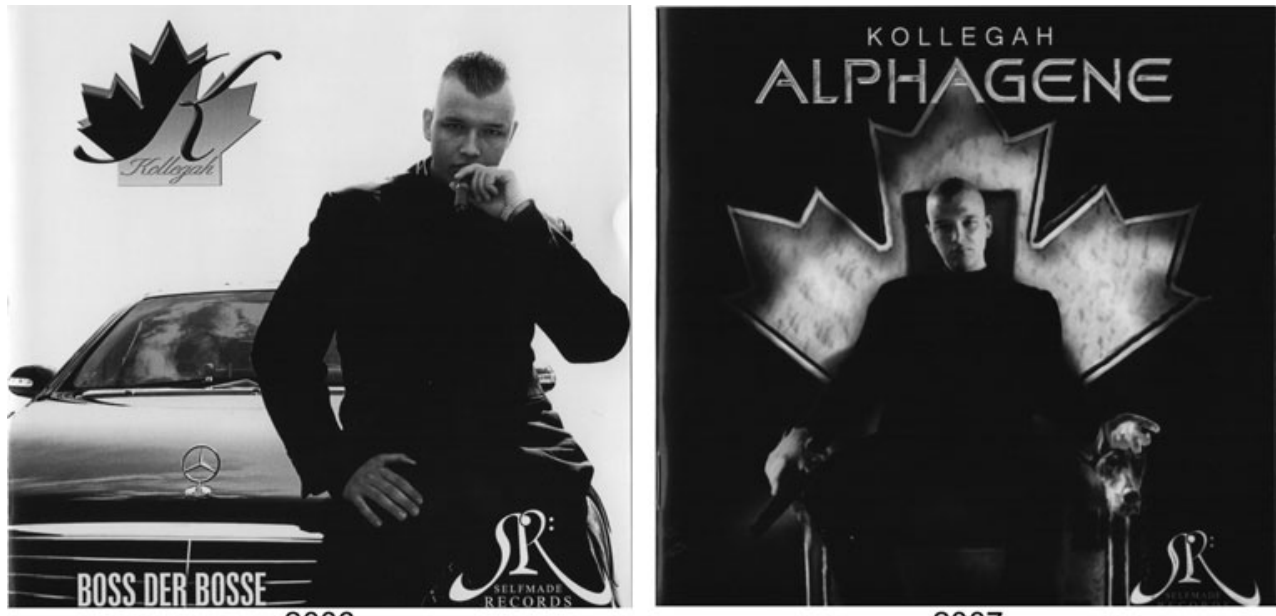

2006

2015

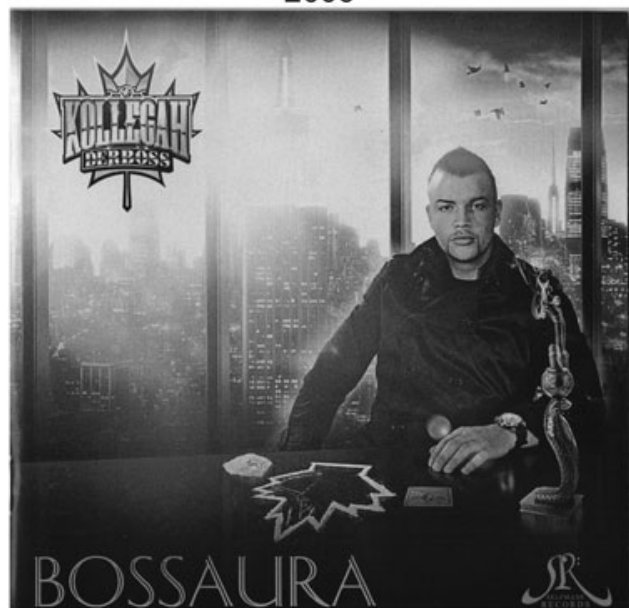

2011

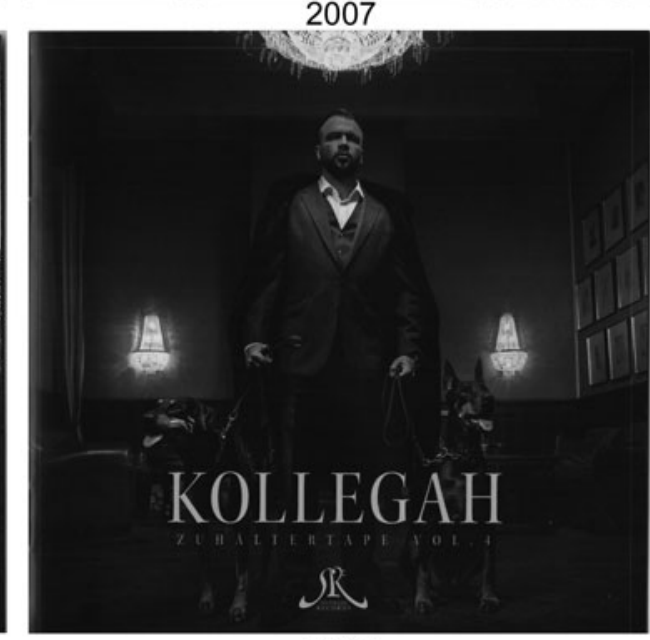

Figure 4. Scans of Kollegah album covers from 2006 to 2015.

aspects and strategies of his American idols and various aspects of hip-hop cultures. By embodying this knowledge and these skills, he also raises his symbolic and economic capital. In order to be regarded as the boss, he develops and flaunts his lyrical capacities, and begins to transform his physical appearance too: from that of a rather juvenile teenager to a testosterone-driven bodybuilding male (see Figure 4).

He exaggerates his physical and financial transformation in interviews and songs and even offers his own commercial programme called Bosstransformation, ${ }^{2}$ which is based on gym workouts and a diet and motivation plan. Besides selfoptimisation, this transition programme clearly focuses on the kinds of hypermasculinity and bodily representations that are also quite common in US gangsta rap. The information provided on his website includes the claim that more than 10,000 participants have already joined (and paid for) this programme. This clearly

${ }^{2}$ see: http://deine.bosstransformation.com (retrieved 25 January 2016). 
illustrates a transitional act of converting different types of capital (embodied cultural capital to symbolic capital to social capital and, ultimately, economic capital).

Furthermore, he acts as an advertising medium. He first endorsed a fashion label in 2014, before establishing and promoting his own sports-oriented fashion label called Deus Maximus (Greatest God) in 2015. So - like his American idols Kollegah has managed to start his own (sub)company, and enter value creation alongside the value chain of the music business, clearly focusing on his 'self-made' career and independent economic situation. Again, this fits perfectly with the theoretical ideas of both acoustic capital and attention economy: he has learned how to play 'the game' himself or via peer-groups and social media, gained skills and expertise in artistic and economic areas, become renowned for this expertise and is, ultimately, able to convert these into economic capital.

\section{Analysis II}

\section{Flow and rhyming skills}

To illustrate his types of capital a little further, two different song lyric extracts were chosen for a more in-depth analysis of his technical and signifying skills, and flow. The first is from his first studio album Alphagene (2007), and the second is from his 2015 release Zuhältertape Vol. 4 (2015). His skills are analysed with regard to wordplay, double time and double-rhyme rapping within a two-part visualisation of the extracted passages, following the approach by Oliver Kautny, as shown above.

\section{(A) Veni Vidi Vici}

This track is number two on the track list of his first full studio album. There is no official music video available for this track. The title already indicates the direction of his entire artistic development and the story it was to highlight: I came, I saw, I conquered. He uses a mixture of German language and a few Anglicisms, which is a signature aspect of his own style. Whenever fragments of the ghetto or pimp narrative (e.g. violence, prostitutes, drugs) are constructed in his lyrics, Kollegah usually uses the original American expression rather than translating it. This may be an attempt to illustrate his own knowledge and expertise and, accordingly, his acoustic capital. He uses those expressions and adds his own sexist, misogynist, offensive and violent flavour in German. According to Martin Sierks, Kollegah is a good example for a development in German rap that began at the start of the new millennium: he uses assonances a lot, as well as weak rhymes, homonyms, homophones and elaborate rhyme schemes (the latter not that often, cf. Sierks 2013, p. 46). These allow for two, three, four or even five syllables in his end rhymes. Deviations from classical rhyme schemes and the use of assonances enable rappers to create a higher number of rhyming combinations than more conservative poetic approaches.

Accordingly, this first example features three-syllable endings (Rapdeutschland, Westdeutschland, all the end rhymes are printed in bold) and four-syllable endings in double rhymes (Topmodell-Look, Block in der Hood, offenen Bruch), in combination with double-timed phrasing. To better illustrate the flow of these lyrics, the stressed syllables are underlied: 
Alphagene, Mutterficker

damit ändern sich einige Dinge von nun an in Rapdeutschland

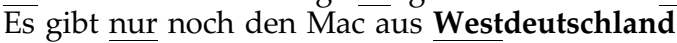

Gegenüber dem Dreck aus Restdeutschland

Sieh den Badboy an - Topmodell-Look

Kids hörn die Tapes im Block in der Hood

Bodybuildermukke, komm in meine Gegend

und du kommst nicht davon ohne offenen Bruch

Vollkommen ohne triftigen Grund,

steck ich deiner Mutter meinen Dick in den Mund

Nehme meine Gun erlege damit alle Member deiner Crew nichts nutziger kiffender Jungs

Wir übernehmen den Markt hier, guck mal ich sags dir

Du spürst es, das liegt einfach in der Luft wie ein Fakir. (Kollegah 2007)

Alpha genes, motherfucker, this is gonna change a few things in Rap-Germany. There is only the mac from West-Germany, compared to the crap from Rest-Germany. Look at this bad boy: top model-look. Kids listen to the tapes in their block, in the hood. Body builder music, come to my hood and you won't get away without an open fracture. Without any compelling reason, I'll stick my dick in your mother's mouth. I'll take my gun and kill all the members of your worthless pot-smoking kids crew. We will take over this market, look, I tell you. You're gonna feel it, it's in the air like a fakir. (Translation: MA)

Looking at the more precise musical notation of his raps (see Figure 5), the reasons why Kollegah has been respected for being a skilled rapper from the very beginning of his career become even more clear: his play on words is accompanied by a range of rhythmic versatility. He switches easily back and forth between binary and ternary time and fast double-time pronunciation, creating a very flexible and driving general rap flow.

\section{(B) Pitbulls \& AKs}

The track is number 14 on this 2015 album. The title itself is a strong signifier of his central narrative: the life of a pimp and drug dealer. Though it is quite clear that Kollegah probably does not own an AK-47 machine gun (owing to German gun laws), it is this type of gun model in particular that is frequently used in rap lyrics as a signifier or stereotype of ghetto violence and pimp life (e.g. by Snoop Dogg, 2Pac, Kendrick Lamar, Lil Wayne etc. ${ }^{3}$ ). Pitbulls are another strong signifier of either pimps or specific types of criminal elements. Furthermore, Kollegah once again integrates Anglicisms into his lyrics and makes references to current socio-political developments (the Anonymous movement) or Internet phenomena (Figure 6):

Suburbane Ghetto-Belletristik, harte Schale, chauvinistischer Kern

Sinkt mein Schiff mal im Meer, dann heißt es: 'Koks und Kinder zuerst!'

Du wimmerst vor Schmerz, denn ich pulle die Beretta, Rest in Peace

Und Junkies in der Stadt suchen auf Ecstasy

Das goldene Ticket in meine Meth-Fabrik - Crack und Speed

Für mich schuften Bitches sogar mit kurzem Minirock im Dezember

Mit einem aufgesetzten Lächeln wie Anonymous-Member

Wannabe-Gangster zahlen mir Schutzgeld per Western Union

3 Examples: Snoop Doog, 'A Nigga Witta Gun', The Chronic, Interscope, 07266, 1992. Trina \& Lil Wayne, 'Wowzerz', I Am Not a Human Being II, Young Money, 06025, 2013. Kendrick Lamar, 'Dont Understand', The Freshman Class: The Mixtape, 2011. 


\section{Kollegah: Veni Vidi Vici \\ (Album: Alphagene) \\ 2nd half verse 1}

Transcription: M. Ahlers
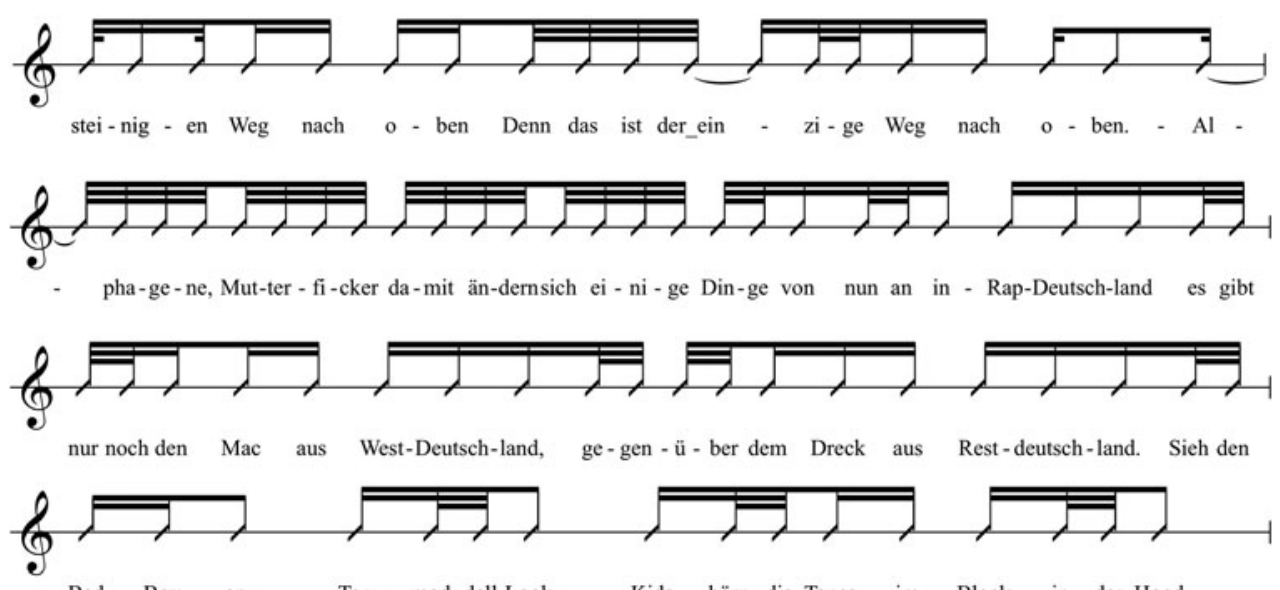

Bad Boy an, - Top - mod-dell-Look. Kids hörn die Tapes im Block in der Hood -

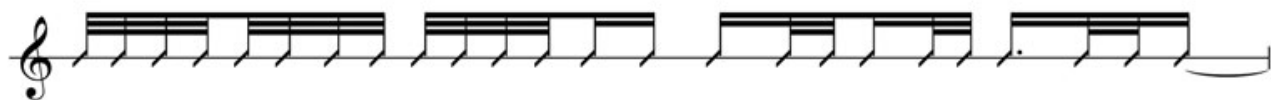

Bo-dy-buil-der-mu-cke,komm in mei-ne Ge-gend und du kommst nicht da-von oh-ne off - enenBruch.Voll -
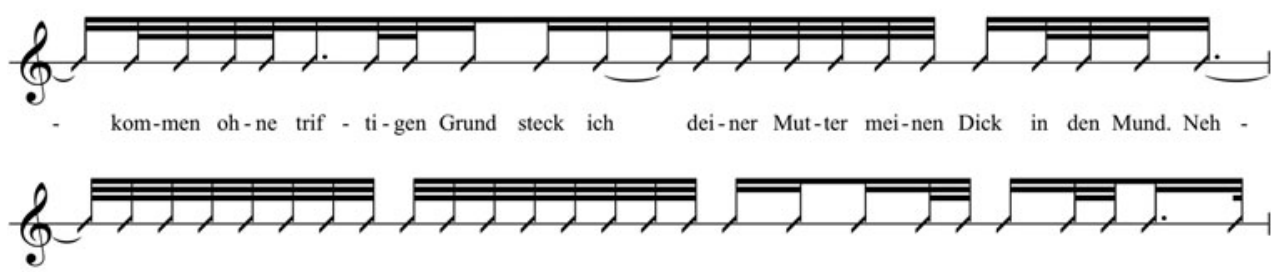

me mei-ne Gun er - le - di - ge-da-mit al - le Member dei-nerCrew nichts - nutz - i - ger kif - fen-derJungs. Wir -

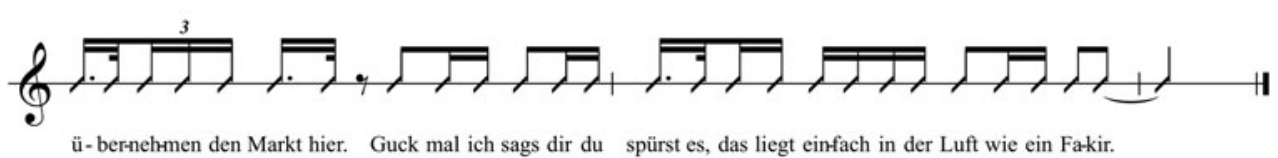

Figure 5. Rhythmic notation (approximate) of 'Veni Vidi Vici'.

Denn sonst findet man sie als Leichen im Block wie Gletschermumien. (Kollegah 2015)

Suburban ghetto fiction, tough on the outside, a chauvinist on the inside. If my ship starts sinking, people say: cocaine and children first! You whimper in pain, coz I'm pulling out my Beretta, rest in peace. And junkies on ecstasy in the city are looking for the golden ticket to my meth factory - crack and speed. Bitches work for me in short skirts even in December, with a fake smile just like Anonymous members. Wannabe gangsters pay me protection money via Western Union. Because if they don't, their bodies will be found in a block, like mummies in a glacier. (Translation: MA)

In this musical notation, we can see that Kollegah's skills are even more highly developed than they were about eight years ago, even though literary scholars still refer to them as merely 'medium-complex wordplay' (cf. Snuszka 2015, p. 69). However, in particular, his rhythmic versatility and his ability to switch from 
Pitbulls und AKs

(Album: Zuhältertape Vol.4)

Begin 2nd verse

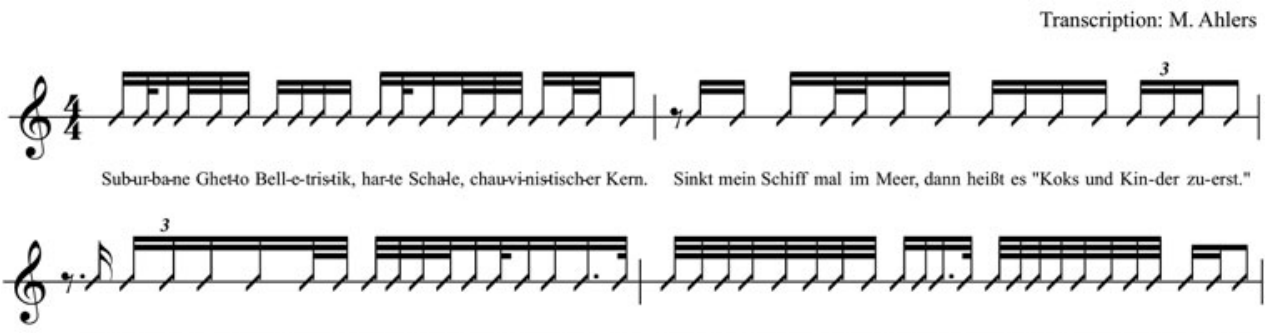

Du wimmerst vorSchmerz,denn ich pul-le die Be-ret-ta, rest in peace und Junkies in derStadt suchen auf Ecrary das goldene Ticket in meine MethFabrik.
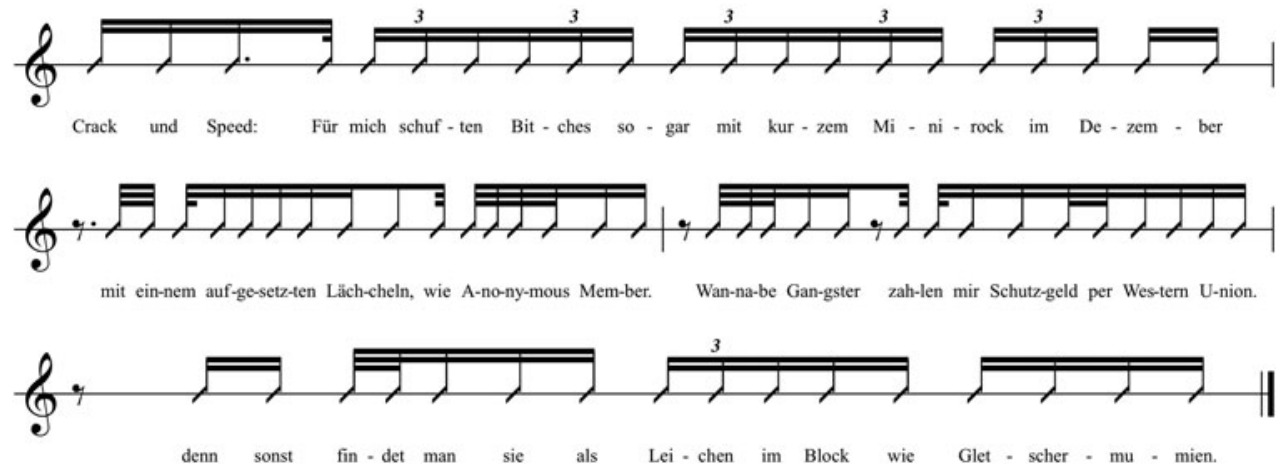

Figure 6. Rhythmic notation (approximate) of 'Pitbulls \& AKs'.

standard binary time to double time, followed by delaying ternary passages, are more elaborate today than at the beginning of his career.

The official music video for this track visualises Kollegah's ghetto and pimp activities, showing black and white images of prostitutes, drugs, guns, pitbulls, expensive cars, cage fighting and men working out in red-light district surroundings. ${ }^{4}$

An analysis of the two tracks shows that both of them have a rather slow basic tempo, ranging from 70 to 82 beats per minute. The harmonic structures are - like most of Kollegah's instrumentals - kept simple and highly repetitious. Veni Vidi Vici consists mainly of two alternating chords (Am-Em/a), a pendulum movement that is sometimes interrupted by an E-major chord. In Pitbulls $\mathcal{E} A K s$, the harmonic structure is $\mathrm{G} \# \mathrm{~m} / \mathrm{d} \#-F \# / \mathrm{c} \#-E / \mathrm{b}-\mathrm{E} 7 / \mathrm{b}$ and $\mathrm{G} \# \mathrm{~m} / \mathrm{d} \#-\mathrm{F} \# / \mathrm{c} \#-\mathrm{E} / \mathrm{b}-\mathrm{F} \# / \mathrm{c} \#$. The overall sound of the productions regarding the long types of reverb being used is quite deep. While the first track has orchestral and choral samples, the latter is even more reduced with regard to the number of instruments or samples and its overall arrangement. This provides more space for the main vocals to be easily understood. Both of the tracks might be perceived as rather martial. Another interpretation might link them to the 'anthems' that are played when boxers enter the arena at a main fight event,

\footnotetext{
${ }^{4}$ https://www.youtube.com/watch?v=pa77LGHv4jQ
} 
offering an ideal tempo for head-nodding, but also obscene and aggressive lyrics to impress one's opponents in the ring.

\section{Analysis III}

\section{Media and commercial activities}

At a very early stage in his career, Kollegah began to explore and use social media for his own interests. He regularly releases videos on his YouTube channel, which used to be called Bosshaft (boss-like) and is now called Alpha Music Empire, ${ }^{5}$ and which is followed by more than 1.12 million people and, as of January 2016, had been accessed close to 100 million times. He shoots short movies that focus on his (imaginary) gangsta life, and has even published cartoons based on his artistic narrative and persona. In an article published in the German weekly magazine Spiegel, Aleksandar Jozvaj (2013) asserts that these activities can compete with or even supersede traditional music marketing channels such as radio, print or television. Jozvaj identifies actors of hip-hop cultures as being the ones who took advantage of these new possibilities and strategies of economic and artistic empowerment at an early stage. It appears that Kollegah was successful in this, at least concerning aspects of attention economy, later also in terms of economics, because not only his fans on the Internet, but also the 'serious' or established media reacted by inviting him to take part in in-depth talk shows or producing TV specials or features on his virtuosity in doubletime rhyming. All this changed again in 2018 after the scandal that followed the release of Jung, brutal, gutaussehend 3, as will be illustrated below.

\section{Media analysis: ambiguity and authenticity}

For this third and last part of the case study, a media analysis ${ }^{6}$ was carried out which included four types of data: (1) comments and articles on the largest German Internet pages on rap (rap.de; hip-hop.de, juice.de, etc.); (2) fan performances/re-enactments of Kollegah on YouTube; (3) a special issue of the German music magazine Musikexpress on 'Deutschrap'; and (4) TV specials or features on Kollegah as 'Germany's fastest rapper'.

Looking at these sources, the ambiguity of Kollegah's perception becomes clear. This needs to be negotiated, while taking into account the following statement by German rap researcher Oliver Kautny:

Mit Blick auf die HipHop-Szene sollte zudem nicht der Fehler gemacht werden, die Produktion sowie die Rezeption von Flow auf Virtuosität bzw. Komplexität zu reduzieren. Zahlreiche Rapper und Fans bewerten Authentizität höher als musikalisch-sprachliche Fähigkeiten, woraus sich die Bekanntheit und Bedeutung von Rappern wie 50 Cent oder Massiv erklären lassen. (Kautny 2009, p. 166)

Regarding the hip-hop scene, one should not make the mistake of reducing the production and reception of flow to virtuosity or complexity. Numerous rappers and fans value authenticity more highly than musical or linguistic skills, which helps explain the prominence and significance of 50 Cent or Massiv [a German hardcore rapper]. (Translation: MA)

\footnotetext{
5 https://www.youtube.com/channel/UCzmO7GegLke-jb5uZSQ9_HA

${ }^{6}$ A special thank you to Madeleine Eggers who supported this part of the analysis.
} 
Surprisingly, Kollegah manages to overcome the importance of being viewed as real or authentic. There is some online controversy on him not being a 'real' pimp, yet his virtuosity, skills and persona have allowed him to cash in on a sort of 'entertainment factor':

Sicherlich ist sein ganzer Auftritt fake. Er ist weder Zuhälter, noch hat er Schusswaffen oder zehn Dobermann Welpen in rosanen Pelzen. Aber das ist mir scheissegal. Er tut das was ein Rapper zu tun hat. Er entertaint. Er hat ein Ego, eine Figur erschaffen und die machen spass. Basta. (User: Grandmother Flash, URL: http://hiphop.de/diskussion/kollegah-wasmeint-ihr, date of retrieval: November 9th 2016)

Of course his entire act is fake. He neither is a pimp, nor does he own guns or ten Doberman puppies in pink fur coats. But I don't give a shit. He does what a rapper is supposed to do: he entertains. He has created an ego, a character, and these are fun. Period. (Translation: MA)

By the use of demarcation on in-depth talk-shows, Kollegah might be able to further differentiate his perception in the media and by his fans: in his latest interviews, he makes a clear distinction between Kollegah, the boss, and Felix Blume, the private individual behind this persona. And he claims that his fans are able to do so too. Virtuosity and entertainment clearly override any obstacles of realness here.

Fans try to imitate his tempo and flow on various web channels, even competing with his double-time rapping (see https://www.youtube.com/watch? v=FSngAyWAvow, date of retrieval: November 9th 2016). Because Kollegah launched his career and later his own business with a very firm grounding in social media, these sorts of reactions and types of feedback would appear to be obvious. He can of course use these kinds of back-channels too.

Altogether, this raises Kollegah's attention and social capital. Because of this, he has also found his way into the German arts pages, serious journalism and even academia, which again adds to his symbolic and economic capital. This is still quite unusual for a gangsta rap artist in Germany. However, the media itself actively supports this process: the special issue of Musikexpress includes a card game for four people. For this purpose, the editors of the magazine analysed 32 German rap artists, including a lyrical corpus of 600,000 words. Not very surprisingly, the Kollegah card wins some of the categories (e.g. 'Vocabulary'), while coming second in others (e.g. 'Offended Mothers'). In addition, one can clearly see the expression 'FAKE' printed above his portrait (see Figure 7).

Lastly, both public networks ${ }^{7}$ and commercial television featured Kollegah because of his virtuosity. This fits in perfectly with the German ideals of being the country of 'Dichter und Denker' (poets and thinkers), or the cult of the genius that has been around since the times of Mozart, Beethoven and others. Yet gangsta rap artists have never before been invited to perform an eighteenth-century ballad by Johann Wolfgang von Goethe ${ }^{8}$ at high speed, competing with an award-winning fast speaker listed in the Guinness book of records. It seems as if the German media is completely aware of this seemingly awkward setting. Yet in the end - of course? - the underdog rapper beats the distinguished old man.

\footnotetext{
7 See: https://www.youtube.com/watch?v=xz60JU74FMY, date retrieved: 11/9/2016.

8 See https://www.youtube.com/watch?v=_gb2rO80s_g, date retrieved: 11/9/2016.
} 


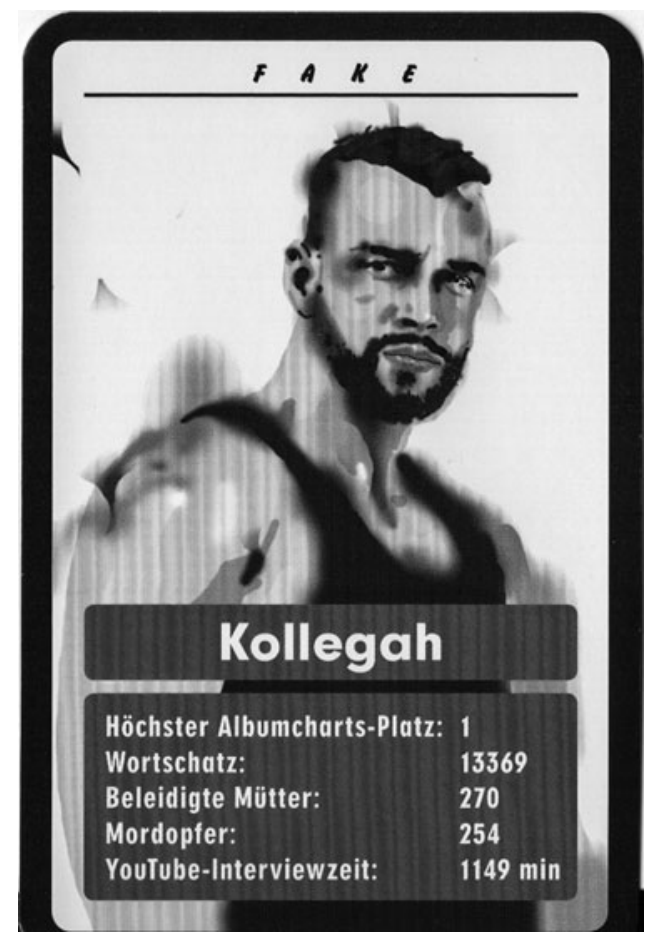

Figure 7. Scan of game card Kollegah, Musikexpress, November 2016.

\section{The scandal of 2018}

As mentioned before, the album Jung, brutal, gutaussehend 3 (JBG3), originally released in December 2017, was nominated for the Echo music industry prize for selling more than 100,000 copies (within the first eight days, later more than 200,000), and with the first single release immediately reaching the top of the German charts. Even though both predecessors of this collaboration album released by Kollegah and Farid Bang had already been rated as not suitable for minors, and with an ethical committee that was introduced to analyse the awardees and their albums, no one made the decision to disinvite the rappers from the official ceremony. Instead, it was Campino, the singer of the German punk band 'Die Toten Hosen' who was chosen to address the contents of the album in depth. He became music industry's mouth piece. This album - besides its mixture of misogynist, sexist, violent and homophobic language - also features some anti-Semitic passages. After Campino's speech, ${ }^{9}$ which featured a strong indictment of gangsta rap and also called for better moral standards (talking about 'shame' and 'scandal') a huge dilemma emerged all of a sudden: How could this have happened? Who was to blame? What was to be done next?

Once again, ambiguity and double moral standards came to light. While artists began to return their awards and members of the ethical committee quit their positions, record companies waited and only suspended their contracts: because after this

\footnotetext{
9 https://www.youtube.com/watch?v=3PmFtCyg-88
} 
scandal, record sales soared, thanks to a huge increase in media and social attention. Yet the industry's reactions in general were quite poor as none of the companies officially released a clear statement on these issues. After a while, it became clear that the reputation of the Echo prize had been severely damaged. As a result, the German music business association officials decided to end this award. ${ }^{10}$

The debate on artistic freedom, freedom of speech and questions of whether this constituted an incitement to hatred is ongoing. Yet the German courts supported artistic freedom and deemed the lyrics highly offensive, but also genre-specific. ${ }^{11}$

\section{Discussion}

In this article, the German gangsta rap artist Kollegah was selected for a case study both because of his recent commercial success and because of the different types of prizes he has recently won, not only for his music but also for success on social media. By now, he has clearly become a huge and highly controversial German media phenomenon, both on the Internet and within traditional media settings. Because of his specific set of acoustic capital gained from his sociocultural background, knowledge of hip-hop's narratives and stereotypes, education, as well as being a skilled and virtuosic rapper and signifier, but also a self-deprecating person, Kollegah was able to cross over markets and possibly attract different audiences.

By applying the theory of acoustic capital, it can be shown that he uses different aspects and types of knowledge and virtuosic skills to constitute this specific type or set of capital and his artistic persona. He is also quite effective in converting or transferring it into attention capital - and ultimately into economic capital. In 2012, Stephan Szillus wrote:

Heute dauert es keine zehn Jahre mehr, bis ein neuer Trend in Europa adaptiert wird. Stattdessen ist die große Zeit des Gangsta-Rap sowohl in Amerika als auch in Deutschland vorerst vorbei. Gleichzeitig hat sich Gangsta-Rap als festes Subgenre innerhalb der HipHop-Kultur etabliert, dass ein komplettes Aussterben dieses HipHop-Zweiges äußerst unwahrscheinlich ist. Vielmehr wird er in Form einer Parallelgesellschaft im Internet weiter existieren und bei nächster Gelegenheit auch wieder ein Erfolgsmodell hervorbringen, sofern sich eine Figur findet, die über die Grenzen dieser Parallelgesellschaft hinaus eine Identifikationsfläche bietet. (Szillus 2012, p. 63)

Today, it takes less than ten years for a new trend to be adapted in Europe. Instead, the heyday of gangsta rap is over - both in America and in Germany. At the same time, gangsta rap has been established as a fixed subgenre of hip-hop culture, making it highly unlikely that this particular branch of hip-hop will die out entirely in the near future. On the contrary, it will continue to exist as a parallel society on the Internet and produce the next success story as soon as a suitable artist appears: one who can cross the boundaries of this parallel society and offer people something they can identify with. (Translation: MA)

Just a few years later, Kollegah can be regarded as the next (commercial) success story that followed the (Aggro) Berlin years. His commercial success already exceeds that of most of the gangsta rappers of the early years of the second millennium. He

${ }^{10} \mathrm{http} / /$ www.musikindustrie.de/news-detail/controller/News/action/detail/news/neuanfang-fuer-dendeutschen-musikpreis/

11 https://www.tagesspiegel.de/kultur/nach-dem-echo-eklat-ermittlungen-gegen-kollegah-und-faridbang-eingestellt/22698946.html or: https://spex.de/kollegah-farid-bang-urteil-gangsta-erwartungenerfuellt/ 
also offers a new type of persona: respected for his lyrical and signifying skills, but no longer as dependent on aspects of authenticity as the gangsta rappers before him. Kollegah is even allowed to overdo every cliché and to cross over into underground, subcultural and even highbrow markets, while deliberately transgressing moral boundaries. Kollegah serves an excellent example of the artistic appropriation of gangsta rap cultures. And he can be seen a new type of 'musicpreneur', or artrepreneur (Brink 2011; Engelmann et al. 2012) within the music business, no longer passive and dependent, but active and in control.

But in addition - after the recent developments around the anti-Semitic scandal the boundaries also appear to be very obvious: after causing a controversy that ended the music prize Echo, he might be remembered not as a business man and skilled gangsta rapper-virtuoso with a fake identity, but as the artist who triggered a societal debate on artistic freedom and morals in Germany.

\section{References}

Anders, P. (ed.) 2007. Poetry Slam: Live-Poeten in Dichterschlachten. Ein Arbeitsbuch (Mühlheim, Verlag an der Ruhr)

Barth, D. 2013. 'In Deutschland wirst du zum Türken gemacht! oder: Die Geister, die ich rief, werd ich nun nicht los', in Diskussion Musikpädagogik: Musikunterricht und der allgemeinbildende 57, pp. 50-58

Becker, J. 1996. 'Zwischen Integration und Dissoziation: Türkische Medienkultur in Deutschland', in Aus Politik und Zeitgeschichte, 44, pp. 39-47

Bennett, A. 2004. 'Hip-Hop am Main, rappin' on the Tyne: hip-hop culture as a local construct in two European cities', in That the Joint! The Hip-Hop Studies Reader, ed. M. Forman and M.A. Neal (New York, Routledge), pp. 177-200

Bock, K., Meier, S., and Süß, G. (ed.) 2007. HipHop meets Academia. Globale Spuren eines lokalen Phänomens. Studien zur Popularmusik (Bielefeld, Transcript)

Böhle, R.C. (ed.) 1996. Aspekte und Formen Interkultureller Musikerziehung: Beiträge vom 2. Symposium zur Interkulturellen Ästhetischen Erziehung an der Hochschule der Künste Berlin (Berlin, Verlag für Interkulturelle Kommunikation)

Bourdieu, P. 1986. "The forms of capital, in handbook of theory and research for the sociology of education," ed. J. Richardson (New York, Greenwood), pp. 241-58.

Bourdieu, P. 1991. Language and Symbolic Power (Cambridge, MA, Harvard University Press)

Bourdieu, P. 1993. The Field of Cultural Production The field of cultural production: Essays on art and literature (New York, Columbia University Press)

Bower, K. 2011. 'Minority identity as German identity in conscious rap and gangsta rap: pushing the margins, redefining the center', German Studies Review, 34/ 2, pp. 377-98

Brink, E. (ed.) 2011. The Artrepreneur. Financial Success for Artistic Souls (London, Papy Publishers)

Bürkner, H.-J., Lange, B., and Schüßler, E. 2013. 'Akustisches Kapital. Perspektiven auf veränderte Wertschöpfungskonfigurationen in der Musikwirtschaft', in Akustisches Kapital. Wertschöpfung in der Musikwirtschaft, ed. B. Lang, H.-J. Bürkner and E. Schüßler (Bielefeld, Transcript), pp. 9-41

Carter, S. (ed.) 2010. Jay-Z Decoded (New York, Random House)

Dietrich, M. (ed.) 2015. Rap im 21. Jahrhundert. Eine (Sub-)Kultur im Wandel (Bielefeld, Transcript)

Dietrich, M., and Seeliger, M. (eds.) 2012. 'Deutscher Gangsta-Rap. Sozial- und kulturwissenschaftliche Beiträge zu einem Pop-Phänomen', in Cultural Studies, 43, ed. L. Grossberg (Bielefeld, Transcript)

Elflein, D. 1998. 'From Krauts with attitudes to Turks with attitudes: some aspects of hip-hop history in Germany', Popular Music, 17/3, pp. 255-65

Elflein, D. 2014. 'HipHop', in Populäre Musik. Geschichte - Kontexte - Forschungsperspektiven, eds. R. von Appen, N. Grosch and M. Pfleiderer (Laaber, Germany, Laaber), pp. 165-75

Engelmann, M., Grünewald, L., and Heinrich, J. 2012. 'The new artrepreneur - how artists can thrive on a networked music business', in International Journal of Music Business Research, 1/2, pp. 31-45

Friedrich, M., and Klein, G. (eds.) 2003. Is this Real? Die Kultur des HipHop (Berlin, Suhrkamp)

Gebesmair, A. 2018. Populäre Musik, in Mediensoziologie: Handbuch für Wissenschaft und Studium, ed. D. Hoffmann and R. Winter (München, Nomos), p. 229

Gossmann, M. 2012. 'Witz schlägt Gewalt? Männlichkeit in Rap-Texten von Bushido und K.I.Z', in Deutscher Gangsta-Rap. Sozial- und kulturwissenschaftliche Beiträge zu einem Pop-Phänomen, ed. M. Dietrich and M. Seeliger (Bielefeld, Transcript), pp. 85-107

Güler Saied, A. (ed.) 2012. Rap in Deutschland. Musik als Interaktionsmedium zwischen Partykultur und urbanen Anerkennungskämpfen (Bielefeld, Transcript) 
Güney, S., Pekman, C., and Kabas, B. 2014. 'Diasporic music in transition: Turkish immigrant performers on the stage of "Multikulti" Berlin', Popular Music and Society, 37/2, pp. 132-51

Güngör, M., and Loh, H. (eds) 2002. Fear of a Kanak Planet - HipHop zwischen Weltkultur und Nazi-Rap (Höfen, Austria, Hannibal Verlag)

Heckmann, F. 2015. 'Identifikative Integration', in Integration von Migranten. Einwanderung und neue Nationenbildung, ed. F. Heckmann (Wiesbaden, Springer VS Verlag), pp. 193-204

Herzberg, M. 2014. Musik und Aufmerksamkeit im Internet: Musiker im Wettstreit um Publikum bei YouTube, Facebook \& Co. (Marburg, Tectum)

Heyer, R., Wachs, S., and Palentien, C. 2013. 'Jugend, Musik und Sozialisation: Forschungsdesiderata und Ausblick', in Handbuch Jugend - Musik - Sozialisation, ed. R. Heyer, S. Wachs and C. Palentien (Wiesbaden, Springer), pp. 465-79

Hofmann, G. (ed.) 2015. 'Musik \& Gewalt: Aggressive Tendenzen in musikalischen Jugendkulturen', Forum Musikpädagogik, 102 (Augsburg, Wißner)

Hörner, F., and Kautny, O. (eds.) 2009. Die Stimme im HipHop. Untersuchungen eines intermedialen Phänomens (Bielefeld, Transcript)

Ickstadt, H. 1999. 'Appropriating difference: Turkish-German rap', Amerikastudien/American Studies, 44/4, pp. 571-8 Ismaiel-Wendt, J. (ed.) 2011. Tracks ' $n$ ' treks: populäre Musik und postkoloniale Analyse (Münster, Unrast)

Jeffries M.P. (ed.) 2010. Thug Life (Chicago, IL)

Jozvaj, A. 2013. 'Deutscher HipHop-Boom: Ruhm ohne Radio', Spiegel Online, 2 December. http://www.spiegel. de/kultur/musik/hiphop-cro-alligatoah-kollegah-genetikk-prinz-pi-youtube-statt-radio-a-932897.html (accessed 1 December 2016)

Kautny, O. 2009. 'Ridin' the beat. Annäherungen an das Phänomen Flow', in Die Stimme im HipHop. Untersuchungen eines intermedialen Phänomens, ed. F. Hörner and O. Kautny (Bielefeld, Transcript), pp. 141-69

Kautny, O. 2015. 'Lyrics and flow in rap music', in The Cambrige Companion to Hip-Hop, ed. J.A. Williams (Cambridge, UK, Cambridge University Press), pp. 101-17

Kaya, A. 2007. 'German-Turkish transnational space: a separate space of their own', German Studies Review, 30/ 3, pp. 483-502

Kimminich, E. (ed.) 2004. Rap: More Than Words. Welt-Körper-Sprache, 4 (Frankfurt, Peter Lang)

Lenz, A., and Paetau, L. 2012. 'Nothing but a B-Thang? Von Gangsta-Rappern, Orthopäden und anderen Provokateuren', in Deutscher Gangsta-Rap. Sozial- und kulturwissenschaftliche Beiträge zu einem Pop-Phänomen, eds M. Dietrich and M. Seeliger (Bielefeld, Transcript), pp. 109-64

Loh, H. (ed.) 2013. Rap@School: Grundlagen für die pädagogische Arbeit mit HipHop (Mainz)

Mager, C., and Hoyler, M. 2007. 'HipHop als Hausmusik: Globale Sounds und (sub)urbane Kontexte', in Sound and the City, ed. D. Helms and T. Phleps (Bielefeld, Transcript), pp. 45-63

Merkt, I. 1993. 'Interkulturelle Musikerziehung', in Musik und Unterricht, 9, p. 22

Meyer, A. 2007. 'Heimatklänge - Lokale Popmusik und transkulturative Prozesse', in Pop insights: Bestandsaufnahmen aktueller Pop- und Medienkultur, ed. T. Krettenauer and Ahlers M. (Bielefeld, Transcript), 35-46

Mitchell, T. 2001. 'Another root - hip-hop outside the USA', in Global Noise. Rap and Hip-Hop Outside the USA, ed. T. Mitchell (Middletown, CT, Wesleyan University Press), pp. 1-38

Ott, T. 2012. 'Konzeptionelle Überlegungen zum interkulturellen Musikunterricht', in Aspekte Interkultureller Musikpädagogik. Ein Studienbuch, ed. A. Niessen and A. Lehmann-Wermser (Augsburg, Wißner), pp. 111-38

Ottersbach, M. (2009). Jugendliche in marginalisierten Quartieren Deutschlands. In Jugendliche im Abseits, ed. M. Ottersbach and T. Zitzmann (Wiesbaden, Springer), pp. 51-74

Pennay, M. 2001. 'Rap in Germany. The birth of a genre', in Global Noise. Rap and Hip-Hop Outside the USA, ed. T. Mitchell (Middletown, CT, Wesleyan University Press), pp. 111-133

Robertson, R. 1995. 'Glocalization: time-space and homogeneity-heterogeneity', in Global Modernities, ed. M. Featherstone, S. Lash and R. Robertson (London, Sage), pp. 25-44

Rollefson, J.G. (2013). "“Gheddos du Monde": sounding the ghetto, occupying the nation from Berlin to Paris, in Hip-Hop in Europe. Cultural Identities and Transnational Flows, ed. S.A. Nitzsche and W. Grünzweig (Münster, LIT Verlag), pp. 227-40

Rose T. (ed.) 1994. Black noise: Rap music and black culture in contemporary America (Middletown, CT, Wesleyan University Press)

Schröer, S. (ed.) 2013. HipHop als Jugendkultur? (Berlin, RabenStück Verlag)

Schütz, V. 1998. 'Transkulturelle Musikerziehung', in Musik transkulturell erfahren. Anregungen für den schulischen Umgang mit Fremdkulturen, ed. M. Claus-Bachmann (Bamberg, Ulme mini)

Sierks, M. (ed.) 2013. 'Themen und Tendenzen des Deutschrap. Dargestellt an ausgewählten Beispielen'. Master's thesis (Hamburg, GRIN)

Snuszka, P.T. (ed.) 2015. Wortspiele von Kollegah und Farif Bang. Ambiguität im Rap (Hamburg, Diplomica)

Solomon, T. 2006. 'Hardcore Muslims: Islamic themes in Turkish rap in diaspora and in the homeland', Yearbook for Traditional Music, 38, pp. 59-78

Soysal, L. 2004. 'Rap, Hiphop, Kreuzberg: scripts of/for migrant youth culture in the WorldCity Berlin', New German Critique, 92, pp. 62-81 
Straub, J. 2012. 'South Bronx, Berlin und Adornos Wien: Gangsta-Rap als Popmusik. Eine Notiz aus sozialund kulturwissenschaftlicher Perspektive', in Deutscher Gangsta-Rap. Sozial- und kulturwissenschaftliche Beiträge zu einem Pop-Phänomen, ed. M. Dietrich and M. Seeliger (Bielefeld, Transcript), pp. 7-20

Szillus, S. 2012. 'Unser Leben - Gangsta Rap in Deutschland', in Deutscher Gangsta-Rap. Sozial- und kulturwissenschaftliche Beiträge zu einem Pop-Phänomen, ed. M. Dietrich and M. Seeliger. Cultural Studies, 43 (Bielefeld, Transcript), pp. 41-64

Taylor, T.D. (ed.) 1997. Global Pop. World Music, World Markets (New York, Routledge)

Tuzcu, P. 2017. 'Ich bin eine Kanackin'. Decolonizing Popfeminism - Transcultural Perspectives on Lady Bitch Ray (Bielefeld, Transcript)

Verlan, S., and Loh, H. (ed.) 2006. 25 Jahre HipHop in Deutschland, 2nd ed. (Höfen, Hannibal)

Weller, K. 2010. 'Explizite Lyrik - "Porno-Rap" aus jugendsexuologischer Perspektive', in Sexuelle Verwahrlosung, ed. M. Schetsche and R.-B. Schmidt (Wiesbaden, Springer), pp. 207-30

White M. (ed.) 2011. From Jim Crow to Jay-Z. Race, Rap and the Performance of Masculinity (Urbana, IL, University of Illinois Press)

Wolbring, F. (ed.) 2015. Die Poetik des deutschsprachigen Rap (Göttingen)

Wurm, M. (ed.) 2006. Musik in der Migration. Beobachtungen zur kulturellen Artikulation türkischer Jugendlicher in Deutschland (Bielefeld, Transcript)

Würtemberger, S. 2009. 'Im Text-Turnier wurde keiner meiner Gegner alt' - Sängerstreit in Sangspruch und Sprechgesang. Dissertation. Universität Stuttgart, http://elib.uni-stuttgart.de/opus/volltexte/2009/4665 (accessed 1 June 2016)

\section{Discography}

Kollegah, Alphagene, Selfmade Records/Universal Music, 14531. 2007.

Kollegah, Zuhältertape Vol. 4., Selfmade Records/Universal Music, 14531. 2015. 